EMPOWER: Jurnal Pengembangan Masyarakat Islam

Vol. 5, No. 2, Desember 2020, hlm. 155-167

e-ISSN: 2580-0973, p-ISSN: 2580-085X

Tersedia online di: http://syekhnurjati.ac.id/jurnal/index.php/empower

Email: empowerjurnal@gmail.com

\title{
Pendidikan Masyarakat di Masa Pandemi COVID-19: Studi Kasus Peran Orang Tua dalam Pendidikan Anak
}

\author{
Sifa Nur Harnisa Dini* \\ (Jurusan Pengembangan Masyarakat Islam, \\ Fakultas Ushuluddin Adab dan Dakwah, IAIN Syekh Nurjati Cirebon) \\ Email: Sifanurhaa@gmail.com
}

\author{
Suryadi** \\ (Jurusan Pengembangan Masyarakat Islam,
} Fakultas Ushuluddin Adab dan Dakwah, IAIN Syekh Nurjati Cirebon) Email: suryadi@syekhnurjati.ac.id

\section{Article History}

Submitted: 11.11.2020, Revised: 09.12.2020, Accepted: 15.12 .2020

\begin{abstract}
Empowerment is an activity in which a person could handle problems or from hard situation thus he has the power to move forward, it could influence for his life in the environment. The empowerment that occurs in parents during a pandemic period actually appears as a respond to unexpected events. A condition and situation that must be done, either in the form of children's learning during the pandemic, as well as taking other active roles based on government policy to stay at home. Parents in Batumirah Village, RT 02/03, realized that during this pandemic period its time parents had to be extra active, especially in various children's activities. Some of the roles played by parents are providing basic introduction to pandemics, increasing the worship, providing motivation, and providing learning assistance at home. This research-based practicum aims to seek the role of parents during the pandemic. The method used is a case study, followed by a moderate participatory approach. While the data used in-depth interviews with research informants. The results showed that the many roles of
\end{abstract}


parents in mentoring were dominated or played by mothers, especially in learning children at home. Even though the role of the family is still running well, there are some parents who cannot play an optimal role or are a little ignore cause of busy. With the reason that parents uneducated so that learning at home cannot be done, as teachers done at school.

Keywords: the role of parent, COVID-19 pandemic

\begin{abstract}
Abstrak
Pemberdayaan merupakan sebuah aktivitas di mana seseorang keluar dari situasi yang tidak berdaya, sehingga mempunyai kekuatan untuk bergerak maju. Dengan demikian ia dapat mempengaruhi kehidupan di lingkungan sekitarnya. Di tengah pandemi, peran orang tua menjadi sangat signifikan. Terutama sebagai pendamping bagi anak-anak yang menjalankan belajar di rumah dengan sistem daring. Misalnya, orang tua di Desa Batumirah, RT 02/03 yang merupakan objek penelitian. Dalam kesehariannya, mereka memiliki tanggung jawab tambahan yakni mendampingi anak belajar di rumah. Praktikum berbasis riset ini bertujuan utuk mengetahui peran orang tua terhadap anak selama masa pandemi. Metode yang digunakan adalah studi kasus, yang diikuti dengan pendekatan partisipatif moderat.

Sedangkan pengumpulan data menggunakan metode wawancara mendalam dengan informan penelitian. Hasil penelitian menunjukkan banyaknya peran orang tua dalam pendampingan didominasi atau banyak dierankan oleh ibu, khususnya dalam pembelajaran anak di rumah. Walaupun peran keluarga masih berjalan dengan baik, namun ada beberapa orang tua tidak dapat berperan secara optimal atau sedikit acuh dengan alasan sibuk. Dengan alasan keterbatasan pendidikan yang dimiliki orang tua sehingga pembelajaran di rumah tidak bisa dilakukan sebagaimana layaknya guru di sekolah.
\end{abstract}

Kata Kunci: peran orang tua, covid -19 


\section{PENDAHULUAN}

Dampak pandemi COVID-19 saat ini menjadi pembahasan yang hangat karena sangat berpengaruh terhadap aktivitas manusia di seluruh dunia. Selain menyerang kesehatan, pandemi COVID-19 juga mengubah pola dan tatanan hidup masyarakat, terutama masyarakat Indonesia.

Kebijakan, program, dan sistem dari lembaga-lembaga turut mengalami pembaruan, menyesuaikan dengan pola hidup masyarakat yang berubah agar tetap berjalan dengan maksimal.

Salah satu lembaga yang sangat terdampak adalah pendidikan. Kita mafhum, institusi pendidikan adalah wadah bertemunya banyak individu dengan latar belakang. Kelompok yang paling riskan terdampak adalah anak-anak. Sehingga para pelajar harus melakukan pembelajaran di rumah atau daring (dalam jaringan atau online).

Setiap anak melakukan pembelajaran daring dan/atau mengerjakan tugas di rumah yang diberikan oleh guru untuk melanjutkan pembelajaran mandiri. Dengan model pembelajaran seperti ini, diharapkan pencapaian prestasi siswa tetap berlangsung sesuai ketentuan dan target tujuan belajar.

Pembelajaran mandiri ini dilakukan secara virtual melalui aplikasi grup Whatsapp, Google Classroom dan yang lebih interaktif dengan Zoom atau Google Meet. Beberapa sekolah juga menerapkan dengan sistem mengerjakan tugas yang diberikan oleh guru masing-masing. Pembelajaran berbasis daring termediasi oleh teknologi informasi yang menciptakan interaksi antara pengajar dan pembelajar, pemberi materi, tugas, dan penilian.

Namun, kebijakan sekolah daring memunculkan masalah terutama bagi orang tua yang menggantungkan pendidikan sekolah sebagai jalur pembelajaran permanen. Peran orang tua memiliki tugas yang lebih besar terhadap pendampingan belajar anak. Yang menjadi soal adalah orang tua yang berada di pedesaan. Kemampuan mereka terbatas dari sisi penggunaan teknologi, ini akan menghambat pembelajaran daring anakanaknya.

Dengan demikian, kemampuan dan keberdayaan orang tua selama masa pandemi harus diperhitungkan dengan maksimal. Sebab, anak-anak 
tumbuh dan berkembang di dalam lingkungan sosial terkecil yaitu keluarga.

Agar peran orang tua sebagai pendamping utama pembelajaran daring lebih optimal, perlu adanya pemberdayaan bagi orang tua. Pemberdayaan merupakan kemampuan (power) orang, khususnya kelompok rentan dan lemah sehingga mereka mempunyai daya agar mampu keluar dan mampu menghadapi kebebasan baik terkait kebutuhan dasar maupun untuk menuju kehidupan yang lebih layak.

Penekanan dalam pemberdayaan orang tua ini menghasilkan keterampilan, pengetahuan, dan kekuasaan orang tua untuk menjalankan fungsi pendampingan pembelajaran daring dengan baik dan optimal.

Menurut penelitian Euis Kurniati ${ }^{1}$, peran utama selama masa pandemi adalah sebagai penjaga, pembimbing, pengembang dan pengawasan terhadap anak. Peran orang tua yang lebih diperlukan meski disibukan dengan pekerjaan.

Selain itu, perang orang tua yang dikutip oleh Subarto adalah mengajarkan dan membangun self-regulating. Di mana anak membangun perilaku yang digerakkan untuk memiliki kemampuan mengatur dalam dirinya (internal). Sedangangkan menurut Winingsih yang dikutip oleh Haerudin ${ }^{2}$, terdapat empat peran orang tua selama pembelajaran jarak jauh (daring), antara lain yaitu; pertama, orang tua memiliki peran sebagai guru di rumah, yang di mana orang tua dapat membimbing anaknya dalam belajar secara jarak jauh dari rumah. Kedua orang tua sebagai fasilitator, yaitu orang tua sebagai sarana dan prasarana bagi anaknya dalam melaksanakan pembelajaran jarak jauh. Ketiga, orang tua sebagai motivator, yaitu orang tua dapat memberikan semangat serta dukungan kepada anaknya dalam melaksanakan pembelajaran, sehingga anak memiliki semangat untuk belajar, serta memperoleh prestasi yang baik. Keempat, orang tua sebagai pengaruh atau director.

\footnotetext{
${ }^{1}$ Euis Kurniati, Dina Kusumanita Nur Alfaeni, and Fitri Andriani, “Analisis Peran Orang Dalam Mendampingi Anak Di Masa Pandemi COVID-19,” Jurnal Obsesi: Jurnal Pendidikan Anak Usia Dini 5, no. 1 (2020).

${ }^{2}$ Haerudin and Et al, "Peran Orangtua Dalam Membimbing Anak Selama Pembelajaran Di Rumah Sebagai Upaya Memutus COVID-19,” 2020.
} 
Keterlibatan orang tua secara langsung terhadap pembelajaran anak selama di rumah, dapat menjadikan orang tua sebagai mentor dan model. Mentor di sini berkitan dengan panduan, pengarahan, serta menentukan goal setting bagi masa depan anak.

Sedangkan model gaya belajar anaknya berkaitan dengan kesukaan sang anak dan seperti apa ketertarikan dalam pembelajaran yang berlangsung. Sebagai model orang tua di rumah dapat memberikan keteladanan dalam berbagai hal. Anak secara tidak langsung belajar tentang adab dari orang tuanya.

Paradigma baru yang muncul dari adanya pengaruh orang tua secara tidak langsung terhadap pembentukan karakter dan pembelajaran anak di rumah, antara lain:

1. Dari kurikulum umum yang padat kepada kurikulum yang berbasis potensi. Dalam paradigma ini maka setiap orang tua harus elektif untuk memunculkan potensi anak.

2. Merdeka belajar. Disini pembelajaran anak terbntuk dengan pembelajaran yang sesuai dengan minatnya, sehingga pengalam pengetahuan di sekolah dapat dihubungkan dengan hal-hal baru di rumah.

3. Pendidikan berpusat pada anak. Menilik kenyataan yang sekarang, bahwa pembelajaran daring berupa teori dan tugas, yang menjadikan orang tua merasa kurang karena keterbatasan pengetahuan. Seharunya diberi bahan inovatif agar dapat memunculkan ide kreatif dalam melakukan daring dengan anak.

Paparan mengenai pengertian peran orang tua di atas merupakan hasil analisis yang dilakukan sebelum dan sesudah adanya pandemi. Kajian yang dilakukan ini sangat penting untuk memahami bagaimana pemberdayaan oang tua terutama di Desa Batumirah dalam mendampingi putra-putrinya selama masa pandemi COVID-19 serta pembelajaran yang dialihkan lebih aktif di rumah.

Kesiapan orang tua dalam menghadapi keadaan saat ini perlu di perhitungkan. Ada beberapa alasan dan penyebab utama yang menjdi keresahan tersendiri bagi orang tua dalam masa pandemi ini, terutama bagi 
orang tua yang tinggal di pedesaan, antara lain di latar belakangi oleh; pendidikan, ketidakpedulian terhadap anak, serta kendala menjalankan peran. Namun, keadaan demikian hanya dari segelintir orang tua, sisanya mereka mulai menyadari keadaan yang terjadi dengan mulai melatih diri agar mampu menghadapi situasi.

Metode studi kasus berupaya menjelaskan fenomena yang sedang diamati secara seksama. Metode ini menjalankan suatu serangkaian kegiatan ilmiah yang dilakukan secara intensif, terinci dan mendalam tentang suatu program, peristiwa, dan aktivitas, baik pada tingkat perorangan, sekelompok orang, lembaga atau organisasi untuk memperoleh pengetahuan mendalam tentang peristiwa tersebut, Sedangkan penelitian deskriptif adalah penelitian yang tujuannya untuk menyajikan gambaran lengkap mengenai suatu fenomena dengn mendeskripsikan sejumlah variabel masalah dan unit yang diteliti.

Dalam mengumpulkan data yang dibutuhkan menggunakan metode interview yang mmenghasilkan data primer. Pengumpulan data ini berupa data primer yang merupakan sumber data pertama di lapangan yang berupa responden dari subjek melalui wawancara. Data yang dibutuhkan ini terkait dengan bagaimana peran orang tua di Desa Batumirah terutama di RT 02/03 terhadap anak dalam situasi pandemi COVID-19.

\section{HASIL DAN PEMBAHASAN}

Berikut merupakan data hasil wawancara yang terkait dengan analisis inti dari peran orang tua terhadap putra-putrinya selama masa pandemi COVID-19. Dari data ini akan ditarik kesimpulan terkait dengan langkah awal pemberdayaan orang tua dalam masa pandemi terhadap pembelajaran anak selama daring.

Tabel 1. Rekapitulasi jawaban responden (ibu)

\begin{tabular}{cclc}
\hline No & \multicolumn{1}{c}{ Pertanyaan } & \multicolumn{1}{c}{ Alternatif Jawaban } & Frekuensi \\
\hline \multirow{2}{*}{1} & Apakah ibu menerapkan & Iya, selalu & 7 \\
& anak untuk hidup sehat? & Iya. Kadang-kadang & - \\
& & Tidak pernah & -
\end{tabular}


2 Apakah ibu memberikan Iya, selalu 5

pendampingan kepada anak Iya. Kadang-kadang 1

dalam mengerjakan tugas Tidak pernah 1

sekolah?

3 Apakah ibu memberikan Iya, selalu 6

bimbingan terhadap anak Iya. Kadang-kadang -

untuk tetap memelihara $\quad$ Tidak pernah 1

nilai agama?

4 Apakah ibu membatasi $\quad$ Iya, selalu $\quad 7$

anak selama masa pandemi Iya. Kadang-kadang -

COVID-19?

Tidak pernah

5 Apakah ibu memberikan Iya, selalu 5

motivasi lebih terhadap Iya. Kadang-kadang 2

anak dalam pembimbingan Tidak pernah

mandiri di rumah?

Tabel 2. Rekapitulasi jawaban responden (bapak)

\begin{tabular}{|c|c|c|c|}
\hline No & Pertanyaan & Alternatif Jawaban & Frekuensi \\
\hline \multirow[t]{3}{*}{1} & Apakah bapak & Selalu & - \\
\hline & menanyakan bagiamana & Kadang-kadang & 4 \\
\hline & sekolah anaknya? & Tidak & 1 \\
\hline \multirow[t]{3}{*}{2} & Apakah bapak membantu & Iya & - \\
\hline & anak dalam mengerjakan & Kadang-kadang & 4 \\
\hline & tugas ketik di rumah? & Tidak & 1 \\
\hline \multirow[t]{5}{*}{3} & Apakah dalam masa & Iya & 4 \\
\hline & pandemi COVID-19 ini & Kadang-kadang & 1 \\
\hline & menjadikan bapak memiliki & Tidak & - \\
\hline & waktu kumpul bersama & & \\
\hline & keluarga lebih banyak? & & \\
\hline \multirow[t]{4}{*}{4} & Jika bapak terlalu sibuk, & Iya & 2 \\
\hline & apakah bapak sering & Kadang-kadang & 2 \\
\hline & $\begin{array}{lr}\text { menanyakan } & \text { bagiamana } \\
\text { pembelajaran } & \text { anaknya }\end{array}$ & Tidak & 1 \\
\hline & melalui telpon dsb? & & \\
\hline
\end{tabular}


5 Apakah bapak memberikan Iya 4 pembelajaran anak terkait Kadang-kadang 1 ibadah, dsb? Tidak

Peran keluarga, dalam hal ini orang tua dalam pendidikan tertera dalam UU No. 20 Tahun 2003 pasal 7 ayat (1) dan (2). Ayat (1) menyatakan, orang tua berhak berperan serta dalam memilih satuan pendidikan dan memperoleh informasi tentang perkembangan pendidikan anaknya. Artinya dalam pasal ini maka setiap orang tua berhak untuk memilih pendidikan yang layak atau sesuai dengan kebtuhan yang di perlukan oleh anaknya. Dan dalam ayat ini maka setiap orang tua berhak mengetahui informasi terkait bagaimana pendidikan yang diperoleh anak dan seperti apa anaknya berkembang di lingkungan sekolah.

Sedangkan Ayat (2) menyatakan, orang tua dari anak usia wajib belajar, berkewajiban memberikan pendidikan dasar kepada anaknya. Dalam keterkaitan ayat ini dengan peran orang tua, adalah bahwa keluarga (orang tua) berkewajiban memiliki peran sebagai pendidik dasar, artinya setiap orang tua harus bisa menumbuhkan pengetahuan yang paling dasar kepada anaknya dengan cara masing-masing.

Dalam Undang-Undang No. 52 Tahun 2009 tentang perkembangan kependudukan dan pembangunan keluarga. Pasal 48 ayat (1) menyatakan bahwa peningkatan kualitas anak dengan melalui pemberian akses informasi, pendidikan penyuluhan, dan pelayanan tetang perawatan, pengasuhan dan perkembangan anak. Dengan demikian keluarga (orang tua) memiliki fungsi yang besar serta tanggungjawab yang lebih terhadap keberlangsungan anak-anaknya atau anggota keluarga dalam menjalani kehidupan.

Pemberian akses informasi dalam peningkatan kualitas hidup anak ini berkaitan dengan jangkauan keluarga memanfaatkan dan mengidentifikasi agar pemahaman individu dalam anggota keluarga (anak) agar tujuan yang diharapkan individu terlaksana. Misalnya dalam hal belajar di rumah (daring), para orang tua mampu menyaring dan siap menjadi perantara utama dalam pembelajaran anak, dengan cara menyampaikan sedemikian rupa sistem pembelajaran agar tetap maksimal. 
Kemudian dalam penyuluhan pendidikan terhadap keluarga. Peran terpenting dalam peningkatan kualitas ini, berkaitan dengan sistem pembelajaran orang tua terhadap anak selama keluar dari pendidikan formalnya. Artinya, orang tua harus memberikan pengajaran selama masa daring, agar anak-anak mampu menghadapi keadaan baru, dengan cara atau sistem yang baik menurut keluarga.

Selain itu, terakait dengan perkembangan anak, orang tua memiliki peran penting. Terutama dalam pembelajaran akademik yang berlangsung selama pandemi. Dengan demikian, penting bagi orang tua menyadari situasi saat ini, agar peran dan kemampuan mereka bisa dijalankan.

Keberhasilan dari peran serta orang tua menurut Marrison, mengemukakan tiga kemungkinan peran orang tua, yaitu;

1. Orientasi pada tugas

Orientasi ini paling sering dilakukan oleh pihak sekolah yaitu harapan keterlibatan orang tua dalam membantu program sekolah. Bentuk peran serta orang tua yang tersebut adalah berkitan dengan orientasi pada tugas sekolah, yaitu membantu anak dalam mengerjakan tugas-tugas sekolah.

2. Orientasi pada proses

Partisipasi orang tua didorong untuk mau berpartisipasi dalam kegiatan yang berhubungan dengan proses pendidikan salah satunya menentukan standar tingkah laku anak dalam berada di lingkungan sekolah. Orientasi proses ini jarang dilaksanakan, karena sekolah seringkali menganggap bahwa umumnya orang tua tidak memiliki keterampilan untuk melaksanakannya.

3. Orientasi pada perkembangan

Orientasi ini membantu para orang tua untuk mengembangkan keterampilan yang berguna bagi meraka sendiri, anak-anaknya, sekolah, guru, keluarga dan pada waktu yang bersamaan meningkatkan peran serta orang tua.

Berdasarkan pemaparan tiga bentuk peran serta orang tua terhadap lembaga akademik di atas, dapat dikatakan bahwa orang tua memiliki peran dan keterlibatan yang besar berorientasi pada tugas, proses dan pada perkembangan. Pembelajaran selama masa pandemi ini, dapat melatih 
orang tua untuk tetap berperan aktif sesuai dengan orientasi yang ditetapkan lembaga pendidikan. Sebab, orang tua tidak lagi dapat menggantungkan peran utamanya dalam pembelajaran anak kepada lembaga pendidikan sepenuhnya.

Berikut merupakan uraian peran orang tua sebagai alternatif pemberdayaan dalam menghadapi situasi dan kondisi pandemi ini, terutama bagi orang tua di Desa Batumirah, antara lain:

\section{Peran Orang Tua Selama Masa Pandemi}

Pertama, menumbuhkan nilai agama anak. Peran orang tua salah satunya adalah memberikan pengenalan terkait ketentuan agamanya. Misalnya dalam agama Islam, setiap anak harus diberikan pengertian mengenai salat, puasa dan sebagainya.

Orang tua yang tinggal dilingkup pedesaan seperti, RT 02/03 Desa Batumirah, mengarahkan kegiatan mengaji untuk anak usia 5 tahun ke atas dalam pengenalan huruf hijaiyah atau TPQ. Dan praktik salat sudah diajarkan, walaupun kebanyakan para orang tua menggantungkan pada pembelajaran pada tingkat madrasah.

Dari data yang diperoleh selama wawancara, kebanyakan orang tua benar-benar mengutamakan pembelajaran agama. Dalam urusan agama peran bapak dalam memberikan pengenalan ibadah sangat penting, ini terbukti bahwa kebanyakan bapak mengajak anaknya untuk ke musala ataupun melaksanakan ibadah di rumah secara berjamaah. Selain itu, selama masa libur $\mathrm{TPQ}$, peran ibu yang memberikan pengenalan dan melatih pembacaan ayat-ayat (jilid) kepada anak-anaknya. Pelatihan ini biasanya dilakukan pada siang hari sehabis duhur, atau malam hari.

Kedua, memberikan pengenalan dasar mengenai COVID-19. Masa pandemi COVID-19, orang tua harus ekstra memperhatikan anak baik dari segi pembatasan anak bermain maupun memberikan pengenalan dasar terkain keadaan yang sedang terjadi. Di lingkungan desa pun, kesadaran para orang tua, terutama ibu menjadi lebih ekstra, dengan membatasi anaknya bermain di luar. Pembatasan ini harus disertai penjelasan mengenai COVID-19. Dengan demikian anak bisa memahami situasi. Dari data yang diperoleh narasumber terutama para ibu yang berperan terhadap 
pembelajaran di rumah, sebagian anaknya memiliki penasan tinggi terkait apa itu COVID-19, dan mereka berusaha menjelaskan dengan baik.

Ketiga, melatih hidup sehat dan bersih. Selama masa pandemi ini, kebanyakan masyarakat Indonesia mengubah pola hidup mereka menjadi lebih higenis dan sehat. Walupun peran orang tua terhadap anak secara mendasar adalah melatih dan memperkenalkan kebersihan sejak dini. Hal ini pun dilakukan oleh beberapa orang tua yang berada di RT 02/03. Mereka melatih anak-anaknya untuk mencuci tangan, terutama menggunakan masker ketika berpergian jauh.

Keempat, menghabiskan waktu bersama untuk anak. Ketika pembatasan anak terhadap dunia luar mereka terjadi, orang tua harus lebih memperhatikan anaknya agar tidak jenuh dan bosan. Walupun di desa kebanyakan anak-anak bermain sendiri tetapi para orang tua juga mulai membatasi bermain, dengan mengatur jadwal bermain mereka dengan teman sebaya.

Agar tidak bosan dengan keseharian, orang tua harus mendampingi anaknya dalam bermain. Walaupun kebanyakan dari anak-anak diperbolehlan bermain gadget, tetapi mereka tetap memberikan dorongan serta motivasi kepada anaknya agar belajar rajin di rumah. Serta peran keluarga pun mereka hadirkan dengan menonton tv bersama.

Namun, ada beberapa orng tua yang benar-benar sibuk dengan karena harus mencari nafkah. Sehingga waktu mereka berada di rumah sangat terbatas. Dengan kasus ini maka peran ibu lebih banyak terhadap anaknya. Walupun demikian, para bapak tetap memperhatikan anaknya dengan menjalin komunikasi dengan ibu, serta bertanya langsung terhadap anaknya.

\section{Peran Orang Tua Terhadap Pembelajaran Anak}

Keluarga dalam hal ini bapak dan ibu menjadi guru aktif bagi anak selama masa pandemi akan terus berlangsung. Dengan adanya kebijakan terkait belajar di rumah atau daring (online), menjadikan peran orang tua harus lebih sadar terhadap pembelajaran anaknya.

Dari data lapangan yang sudah di peroleh, persentase ibu lebih banyak dominan terhadap pembelajaran anak di rumah. Sedangkan bapak 
tetap berperan mencari nafkah, dan lebih banyak menyerahkan pembelajaran kepada ibu.

Kepedulian bapak tetap ada walaupun hanya sekedar bertanya bagaimana perkembangan pembelajaran anaknya, dengan demikian bapak tetap berperan untuk memantau. Ada juga orang tua yang menitipkan pembelajaran anaknya kepada saudara, atau orang yang dekat dengan anaknya.

\section{Kesulitan Orang Tua Selama Masa Pandemi}

Berikut merupakan kesulitan orang tua selama masa pandemi menjalankan perannya: Pertama, keterbatasan pendidikan yang dimiliki orang tua, menjadikan hal ini sebagai kesulitan tersendiri untuk melakukan pembelajaran daring, karena kebanyakan daring dalam bentuk tugas. Kedua, sebagaian besar orang tua di desa menggantungkan pembelajaran dengan di sekolah saja, tidak dalam bentuk les atau pembantu pembelajaran lainnya. Sehingga orang tua ekstra aktif menjadi guru semasa pembelajaran di rumah. Ketiga, kesibukan menjadikan peran salah satu orang tua lebih dominan.

\section{SIMPULAN}

Peran utama yang dilakukan oleh orang tua di Desa Batumirah RT 02/03 selama masa pandemi adalah memberikan pengertian dasar terkait situasi yang terjadi saat ini dengan kemampuan masing-masing, kemudian parang orang tua melatih untuk hidup sehat, serta meningkatkan nilai ibadah di masa pandemi.

Selain itu peran aktif yang dilakukan orag tua adalah mengawasi dalam pembelajaran aktif di rumah dengan mengerjakan dan mengikuti kegiatan sekolah daring anaknya. Namun di sisi lain, kesulitan dirasakan oleh para orang tua terutama karena keterbatasan pendidikan mereka juga kesibukan dalam mencari nafkah. Sehingga peran meraka sebagai orang tua tidak terlaksana dengan baik.

Dengan adanya pemindahan pembelajaran dari sekolah ke rumah, seharusnya orang tua dapat mengambil bagian dan tanggung jawab dalam mengembangkan potensi anak. Cara yang baik bagi orang tua untung 
mengembangkan diri, kreativitas, dan inovasi agar anaknya bisa memiliki kualitas diri sesuai dengan kemampuan.

Hasil kajian ini dapat menjadi acuan sederhana bagi peneliti lain dalam meneliti lebih mendalam. Bagi peneliti yang akan meneliti dengan tema yang sama hal yang harus diperhatikan adalah mengetahui keseharian keluarga selama 24 jam. Agar hasil penelitian bisa lebih mendalam. serta memberikan pertanyaan sederhana kepada anak yang bersangkutan untuk lebih mendapatkan analisis yang tepat.

\section{DAFTAR PUSTAKA}

Ariani, N. "Hubungan Antara Persepsi Anak terhadap Keharmonisan Keluarga dengan Prestasi Belajar". 2011.

Iqbal, Muhammad. "Simulacrum Pendidikan di Era Pandemi”. 2020. Haerudin, and Et al. "Peran Orangtua Dalam Membimbing Anak Selama Pembelajaran Di Rumah Sebagai Upaya Memutus COVID-19," 2020.

Kurniati, Euis, Dina Kusumanita Nur Alfaeni, and Fitri Andriani. "Analisis Peran Orang Dalam Mendampingi Anak Di Masa Pandemi COVID19." Jurnal Obsesi: Jurnal Pendidikan Anak Usia Dini 5, no. 1 (2020).

Subarto. "Momentum Keluarga Mengembangkan Kemampuan Belajar Peserta Didik di Tengah Wabah Pandemi COVID-19". Adalah Buletin Hukum dan Keadilan 4, no. 1 (2020).

Suharto, Edi. Membangun Masyarakat Memberdayakan Rakyat. Bandung: PT Refika Aditama.

Naufin, Febriani, and Wayan Asmara Dewi. "Teori dan Praktik: Riset Komunikasi Pemasaran Terpadu". Malang: UB Press. 2018. 